Article

\title{
OFDI Impact on Private Investment in the Gulf Economies
}

\author{
Syed Hasanat Shah ${ }^{1,2}$, Waqar Ameer ${ }^{3, *}$ and Sarath Delpachitra ${ }^{4}$ \\ 1 School of Economics, Jilin University, Changchun 130012,China; haist@jlu.edu.cn \\ 2 Public Sector Economy Research Centre, Jilin University, Changchun 130012, China \\ 3 School of Economics and trade, Hunan University, Yuelushan District, Changsha 410079, China \\ 4 Institute of Business Research, University Of Economics, 59C Nguyen Dinh Chieu Street DC3, \\ Ho Chi Minh City 700000, Vietnam; s.delpachitra@hotmail.com \\ * Correspondence: waqar.ameer@yahoo.com
}

Received: 12 February 2020; Accepted: 21 May 2020; Published: 1 June 2020

check for updates

\begin{abstract}
Gulf Cooperation Council (GCC) countries are highly dependent on hydrocarbons, which puts them at great risk to maintain stability in the long run. GCC countries need private investment to reduce their reliance on state and diversify their economies apart from hydrocarbon. The role of private investment is crucial to economic stability and development. Literature suggests that outward foreign direct investment (OFDI) can play a vital role in promoting private investment. Therefore, using feasible generalized least squares (FGLS) and panel corrected standard error (PCSE) techniques, we checked the impact of the GCC countries OFDI on private investment and found that OFDI significantly complement private investment in the GCC countries. The complementary impact of OFDI on private investment in the GCC countries can be used as a tool to promote private investment, diversify their economies and hedge against the pitfalls of addiction to the hydrocarbon.
\end{abstract}

Keywords: OFDI; private investment; diversification; gulf countries; PCSE

\section{Introduction}

The GCC (Gulf Cooperation Council) countries relied heavily on hydrocarbon in the last couple of decades to grow rapidly and maintain better living standards. From 2000 to 2017, hydrocarbon contributed 80 percent of the government revenue, 65 percent of the total exports and 42 percent of the GDP of the GCC countries [1]. The over-reliance on hydrocarbon swelled public investment and discouraged private investment in the GCC countries. Although rich hydrocarbon resources generated sufficient revenue for the government in the GCC countries to avoid economic meltdown in the short run, but the dwindling hydrocarbon reserves, and severe oil price fluctuation put the GCC countries in a difficult position [2]. Scholars suggest that the GCC countries need urgent reforms and more space for private investment in order to maintain economic stability. In the first leg the GCC countries opened their doors for foreign investment while in the second leg they heavily invested abroad in order to connect local firms to global chain of production and thus diversify their economies away from hydrocarbon.

There is a widespread literature on the impact of incoming foreign direct investment inflows FDI in the GCC countries [3-5]; however, the impact of outbound investment on the GCC countries economic well-being is still a mystery, especially when it comes to discover links between OFDI and domestic investment in the GCC countries. Empirical literature suggest that outbound investment can potentially increase local investment given that investing abroad link local investors to the global chain of production [6-9].OFDI can positively affect private investment in source countries if (1) OFDI is financed from the abundant saving and bulging foreign exchange reserves of a country and (2) OFDI 
increase the return of local firms by employing the most efficient factors abroad [10]. In cases where OFDI is motivated to reduce cost, then the outcome can be different. High cost and lack of opportunities encourage firms to relocate production abroad at the cost of local investment. In other words, the two forces of 'complement' and 'substitute' make it difficult to generalize the impact of OFDI on domestic investment [7,11-13].

Therefore, in this study, our main objective is to understand whether the recent surge of OFDI increase or decrease private investment in the GCC countries keeping in view that private investment is the main $\operatorname{cog}$ in the process of economic diversification both in developed and developing countries? Following [8] and [14], we assume that OFDI complement private investment and diversify economic activities in the GCC countries. In case OFDI decreases private investment, then OFDI can degrade the financial structure and the efforts of economic diversification in the GCC countries [10]. Private investment is crucial for economic progress due to its flexibility, connectivity and its absorptive capacity of latest ideas and information. Private investment also plays the role of a buffer against the economic shocks and uncertainties (IMF, 2018). For example, [15] suggested that private investment is more productive and innovative than any other form of investment. The findings of this study provide policy direction to the GGC countries on how to better utilize their scared financial resources.

The rest of the study is organized as follows. Section 1 discusses OFDI, FDI and Capital formation in the GCC countries while Section 2 presents literature review. Section 3 explains the data sources and econometric methodologies. Section 4 reports the results and findings of the study and Section 5 concludes it.

\subsection{Research Hypothesis}

Our main research question and hypothesis to understand the impact of OFDI on private investment in the GCC countries can be described as:

Hypothesis 1 (H 1): OFDI positively contribute to the private investment in the GCC countries;

Hypothesis 2 (H 2): OFDI adversely affect private investment in the GCC countries.

\subsection{OFDI, FDI and Domestic Capital Formation in GCC Countries}

The GCC is a regional intergovernmental political and economic union consisting of Bahrain, Kuwait, Saudi Arabia, Qatar, Oman and the UAE. The charter of the GCC was signed in 1981. Over the course of almost four decades, the GCC has gradually evolved into an integrated economic bloc. Hydrocarbon is the prima facia and the backbone of the GCC bloc. The government revenue, total exports and GDP growth squarely counts on hydrocarbon proceeds.

Hydrocarbon price increased many folds since the charter of the GCC was signed but it never stayed stable. Hydrocarbon prices exhibited severe volatility, e.g., oil price, the main mix of hydrocarbon, increased from \$ 80 per barrel in 2010 to $\$ 106$ per barrel in 2014. By 2016, the oil prices were hovering around $\$ 30$ per barrel; it suddenly jumped to $\$ 70$ per barrel by 2018 . High volatility in the prices of hydrocarbon feeds economic instability and uncertainty in the GCC countries [16]. This problem amplify when we include the changing patterns of global production and the discovery of new energy sources in the equation and consider that the attraction of hydrocarbon is on decline. In this backdrop, the GCC countries need diversification to revamp their economies [17].

According to [18], outbound foreign investment in the GCC countries can indeed be the beginning of a successful transition from hydrocarbon to a diverse economy. Recently, the GCC countries widely invested abroad in strategic sectors such as computations, hotel chains and financial firms as well as in transport and communication, etc. Moreover, one of the basic motives of these endeavors is to promote domestic investment at home. Table 1 shows that OFDI in the GCC countries increased over time in absolute terms; however, the share of OFDI as percent of GDP did not. Rather OFDI as a percent of 
GDP registered decline from 3.8 percent in 2008 to 2.1 percent of the GDP in 2017. Yet, this decline in OFDI in the GCC countries is less than the decline in the incoming FDI.

The shares of public and private investment in the GCC countries are generally pitched against each other and normally the dominant control of the government is blamed for sluggish private investment in the GCC countries [1,17]. Governments in GCC countries hold a major chunk of the local economy and therefore it is considered a hurdle in the process of diversification [1]. However, Table 1 shows that public and private investment in GCC countries as a percent of GDP did not change a lot in the last decade. From 2008 to 2017, private investment in the GCC countries remained within the bounds of 32 to 34 percent of the GDP while public investment vacillated in the range of 20 to 23 percent of the GDP in the same period of time. Table 1 also shows that oil and gas revenue as a percent of GDP exhibit great volatility. Therefore, relying on hydrocarbon is risky business.

Table 1. Investment and hydrocarbon in (GCC) countries.

\begin{tabular}{ccccccc}
\hline Year & $\begin{array}{c}\text { Private } \\
\text { Capital } \\
\text { Formation } \\
\text { (\%GDP) }\end{array}$ & $\begin{array}{c}\text { Public } \\
\text { Capital } \\
\text { Formation } \\
\text { (\%GDP) }\end{array}$ & $\begin{array}{c}\text { OFDI } \\
\text { (\%GDP) }\end{array}$ & $\begin{array}{c}\text { FDI } \\
\text { (\%GDP) }\end{array}$ & $\begin{array}{c}\text { Oil and Gas } \\
\text { as\% of } \\
\text { Government } \\
\text { Revenue }\end{array}$ & $\begin{array}{c}\text { Oil and } \\
\text { Gas as a } \\
\text { of GDP }\end{array}$ \\
\hline 2008 & 33.27 & 20.80 & 3.08 & 4.85 & 20.90 & 37.41 \\
\hline 2009 & 33.50 & 21.49 & 1.37 & 4.49 & 27.16 & 27.11 \\
\hline 2010 & 31.90 & 23.30 & 1.36 & 3.23 & 26.00 & 31.64 \\
\hline 2011 & 28.08 & 21.87 & 2.16 & 2.45 & 32.80 & 40.20 \\
\hline 2012 & 33.36 & 21.66 & 1.29 & 2.57 & 46.42 & 38.89 \\
\hline 2013 & 33.80 & 21.48 & 2.94 & 3.51 & 45.73 & 36.70 \\
\hline 2014 & 34.11 & 20.16 & 1.03 & 2.14 & 41.93 & 33.21 \\
\hline 2015 & 33.05 & 18.08 & 2.41 & 0.31 & 31.85 & 20.82 \\
\hline 2016 & 32.42 & 20.94 & 1.96 & 2.20 & 41.59 & 16.94 \\
\hline 2017 & 34.26 & 20.82 & 2.10 & 1.80 & 44.67 & 19.89 \\
\hline
\end{tabular}

\section{Literature Review}

The empirical literature on the nexus between OFDI and capital formation in home countries is broadly divided into two genres such as complementary and substitute [9].OFDI complements private investment if it link local firms with the global chain of production. Similarly, OFDI can promote domestic investment if it increase the return of the local firm by connecting them to efficient labor and capital abroad [8]. However, when OFDI relocate production from home to host countries then it adversely affect domestic investment [19-23].

The studies supporting the positive and complementary role of OFDI in promoting domestic investment assumes that the main motives of OFDI is efficiency seeking. Efficiency seeking OFDI link the home and the host countries economic activities in such a way that they exploit the economies of scale, reduce costs of production and increase efficiency. Efficiency seeking vertical OFDI complements trade by relocating parts of production chain from home to the host country [24]. Vertical OFDI boost trade in intermediate products between host and home countries and help the home country to access latest technology and technical knowhow [25]. Vertical OFDI do not disrupt domestic production and thus play the role of conduit to promote investment in source countries [26-28].

On the other hand, a number of studies looking at the adverse (substitutions) impact of OFDI suggest that contrary to the impact of vertical OFDI, horizontal OFDI retard production in home country by relocating domestic production abroad. Such OFDI (horizontal) is supposed to substitute home country production with the host country production and thus adversely affecting local 
investment. Some studies are more critical of OFDI and suggest that OFDI not only relocate domestic production abroad, but it also reduce economic activities at home by replacing domestic production with imports [26] while other explored that OFDI squeeze scarce financial resources at home country by venturing out at the cost of local investment $[8,10,23,29]$.

There are four motives for firms seeking to invest abroad such as efficiency-seeking, resource seeking, market-seeking and strategic asset-seeking. The strategic asset-seeking motive of OFDI is of significant importance. Strategic asset seeking OFDI is supposed to improve the domestic investment in source and host countries by bringing in new knowledge and technologies in high spillover sectors [30-33]. A number of studies underscored these theoretical underpinnings. Regarding the aggregate OFDI, there is a positive long-run unidirectional causal relationship running from OFDI to domestic investment in China [14]. Similarly, there is strong evidence of positive spillover impact of OFDI on private investment not only on country level, but also on inter-regional level in China [34]. On the contrary, the macroeconomic cross country analysis was conducted, and results show that increase in OFDI decrease domestic investment [22].Same findings are confirmed by United States, Japan, Germany and the United Kingdom [35]. A similar analysis was conducted for the United States and Germany where they discovered positive long-run effect of OFDI on domestic investment in the US, however, their finding in case of Germany was mixed. They found that outward FDI has positive short run and negative long-run effect on domestic private investment there. This means that OFDI in Germany contributed to domestic private investment in the short run and substitute domestic private investment in the long run [29].

Literature based on neoclassical and Keynesian outlooks view public and the private investment differently [36,37]. Neoclassical support private investment and assume that private capital is the main force which increase efficiency, stimulate creativity and promote diversity. Neoclassical disregard public capital in promoting economic growth and in some cases even they blame public investment for inefficiency [15]. From here a perception emerges which assume that public and private investment generally crowd-out each other and thus clubbing them together can potentially increase the problem of aggregation bias. However, the Keynesians refute this argument and they suggest that public investment actually pave the way for effective utilization of private investment and thus public and private investment crowd in each other. In this study, we want to see whether public investment crowd-in or crowd-out private investment in the GCC countries.

\section{Methodology and Data}

The selection of an appropriate model for empirical analysis in panel data has huge impact on the final outcome. A correct model produces an efficient and consistent results while an incorrect model lead to wrong conclusion. For example, until recently, most of the cross country studies in economics literature wrongly assumed that errors are independently distributed across data. While in reality variables in cross country studies count on each other, particularly in the long run. Therefore, to drop the erroneous assumption of independent errors in cross country panel data and get consistent results, many studies moved away from traditional techniques like panel dynamic OLS [38], panel fully modified OLS approach [39] and panel pooled and mean group tests [40] to new techniques such as cross sectional-ARDL [41,42], GMM [43], FGLS [41,44] and PCSE tests [45].These models not only address the issue of cross country dependence, but they also solve the problems of heteroscedasticity and serial correlation in the panel data. For example, the use of inappropriate techniques report no impact of foreign remittances inflows on labor productivity in [46], however, as soon they addressed the issue of cross country dependence and used an appropriate model, they found a strong and significant impact of foreign remittances on labor productivity.

Our methodological approach is to pool cross-sectional time series. The time series dimension of the pooled data is more problematic than cross-section because observations in timer series are usually not independent [47]. OLS normally indicate an ideal situation where the errors are independent and homoscedastic, but in reality, the error terms deviates from such assumptions and therefore need a 
thorough analysis in application of an appropriate model. The GCC countries are closely connected both in policy orientation, culture and economic activities. They depend on each other in many ways and therefore the possibility of cross-sectional dependence in the GCC countries, especially in case of FDI inflows and outflows, cannot be ruled out. [48] and [49] consider that Cross-correlation occurs very frequently due to spatial spillover effects, omitted common factor and inter-actions within socioeconomic network. We consider that outbound foreign direct investment (OFDI) in one country is not independent of the outbound foreign direct investment in another country in the GCC countries. Same is true for FDI inflows and therefore we suspect the problem of cross-sectional dependence in our panel series.

Panel-based studies normally use ARDL or GMM approached. Although the panel GMM techniques address the issue of endogeneity, but it does not work efficiently in the presence of cross-sectional dependency and structural breaks. System GMM also has limitations in studies based on small N (cross section) and large T (time dimension). On the contrary, Panel CS-ARDL not only take care of endogeneity problem, but it also addresses the issue of cross sectional dependence and capture the long and short run impacts of the variables. However, CS-ARDL technique has certain limitations. It is considered that CS-ARDL is valid only for a panel data with long cross sectional and short time series $(\mathrm{N}>\mathrm{T})[50]$.

Knowing that our time series (25 years) is longer than our cross sectional (6 countries), we dropped the idea of using CS-ARDL and looked for alternate techniques. Literature suggest a number of approaches to address the issue of cross-sectional dependence when $\mathrm{T}>\mathrm{N}$ in panel series. Among them the two, i.e., feasible generalized least squares (FGLS) [41,44] and panel-corrected standard errors (PCSE) [45] received wide attention. Therefore, in this study we rely on FGLS and PCSE techniques (Appendix A).

Though FGLS model is widely popular among the researchers, but [45] identify two important issues in the FGLS model. First, the FGLS by default can only be estimated when the number of time periods $(\mathrm{T})$ is more than the cross section $(\mathrm{N})$. Otherwise, the associated EVCM (error-variance covariance matrix), the base of the FGLS models, cannot be inverted with small $\mathrm{T}$ and large $\mathrm{N}$. Second, the FGLS model tends to produce unacceptably small standard error estimates which render hypothesis testing useless $[45,50]$. At the same time with cross-section heteroskedasticity the OLS standard errors are also inconsistent. Therefore, to address these issues, panel-corrected standard errors (PCSE) convincingly demonstrate that PCSE large-T asymptotic-based standard errors, which correct for contemporaneous correlation between the subjects, perform well in small panels [45]. PCSE preserves the (Prais-Winsten) weighting of observations for autocorrelation but uses a sandwich estimator to incorporate cross-sectional dependence when calculating standard errors. In order to control of heterogeneity, serial correlation and cross sectional dependence in our panel data-based models [50], we regress the following baseline model using the techniques of PCSE (FGLS is used for robustness check).

$$
\text { DPIit }=\alpha \mathrm{i}+\beta \mathrm{i} 1 \text { OFDIit }+\beta \mathrm{i} 2 \mathrm{Zit}+\varepsilon \mathrm{it}
$$

where, $i$ stands for cross-sectional dimension; $i=1 \ldots \ldots$ and time period $t=1 \ldots \ldots$.t and $\alpha i$ represents country specific effects. $\varepsilon i$ it is a random disturbance term of mean zero. $\alpha$ i stands for country specific effects. It is pertinent to mention that the disturbance term in equation (1) is consist of two components, i.e., time invariant and idiosyncratic error components. We assume that the time invariant component is specific to the individual and does not change over time while the idiosyncratic error component is usually assumed to be independent of both the regressors and the individual error components.

DPI in equation (1) represents the domestic private investment in the GCC countries while OFDI is outbound foreign direct investment originating from the GCC countries. $\mathrm{Z}$ is a control variable for GDP growth, interest rate (IR), incoming FDI (IFDI), trade openness (TO), public investment (PUB) and incoming FDI, etc. later we will expand the set of our control variables by introducing the variable of public investment (PUB). Public investment is considered one of the biggest hurdles for private 
investment in the GCC countries. Therefore, the inclusion of public investment will not only better reflect the economic condition of the GCC countries, but it will also contribute to the robustness check of the key results. The final version of our model is given as:

$$
D P I i t=\alpha i+\beta i 1 \text { OFDIit }+\beta i 2 \text { GDPit }+\beta i 3 \text { IRit }+\beta i 4 \text { IFDIit }+\beta i 5 \text { TOit }+\beta i 6 \text { PUBit }+\varepsilon i t
$$

We avoid using lagged dependent variable (LDV) on the right-hand side of the equation in this study because the lagged dependent variables in panel estimations other than Generalized Method of Moments (GMM) produce bias coefficient [51]. Table 2 presents the whole list of our dependent and independent variables along with their source and theoretical justification. The data are available on demand. The range of our data is from 1993 to 2017.

Table 2. Description and source of variables (for GCC countries).

\begin{tabular}{|c|c|c|c|}
\hline Variable & Description & Theoretical Justification & Source \\
\hline DPI & $\begin{array}{l}\text { Domestic Private } \\
\text { Investment. }\end{array}$ & $\begin{array}{l}\text { DPI increases the productivity; help achieve } \\
\text { technical progress and promote economic } \\
\text { activities in a country. Similarly, Private } \\
\text { investment is considered more efficient and } \\
\text { more resilient [15]. }\end{array}$ & $\begin{array}{l}\text { IMF Fiscal Affairs } \\
\text { Department }\end{array}$ \\
\hline OFDI & $\begin{array}{l}\text { Outbound Foreign } \\
\text { Direct Investment }\end{array}$ & $\begin{array}{l}\text { OFDI increase the productivity of firms in } \\
\text { source countries by giving them access to } \\
\text { technology, resources, skills, international } \\
\text { brand names and global markets and thus } \\
\text { promote investment [52]. }\end{array}$ & WDI \\
\hline GDP & $\begin{array}{l}\text { Growth rate of the } \\
\text { GCC countries }\end{array}$ & $\begin{array}{l}\text { GDP growth increases the capacity of an } \\
\text { economy and expand economic activities } \\
\text { which encourage local investment [37]. }\end{array}$ & WDI \\
\hline IFDI & $\begin{array}{l}\text { Incoming Foreign } \\
\text { Direct investment }\end{array}$ & $\begin{array}{c}\text { IFDI increase the efficiency of production and } \\
\text { their exports in host countries by bringing } \\
\text { along latest technology, capital and } \\
\text { management skills [32]. }\end{array}$ & WDI \\
\hline IR & Interest rate & $\begin{array}{l}\text { High interest rate decrease private investment } \\
\text { by raising the real cost of capital however, high } \\
\text { interest rate can increase private investment } \\
\text { given that it encourage saving and investable } \\
\text { funds generally referred as 'conduit effect' [53]. }\end{array}$ & $\begin{array}{l}\text { Relevant Monetary } \\
\text { Authorities from } \\
\text { GCC countries }\end{array}$ \\
\hline PUB & Public investment & $\begin{array}{l}\text { Classical economist considers that public } \\
\text { investment adversely affect economic activities, } \\
\text { especially private investment (Narayan, 2004) } \\
\text { while Keynesian consider that public } \\
\text { investment facilitate private investment [54]. }\end{array}$ & $\begin{array}{c}\text { Fiscal Affairs } \\
\text { Department, IMF }\end{array}$ \\
\hline TO & Trade Openness & $\begin{array}{l}\text { Trade openness diversifies an economy given } \\
\text { that trade interlink economic activities e.g., } \\
\text { increase in exports under vertical integration } \\
\text { promote investment [55]. }\end{array}$ & WDI \\
\hline
\end{tabular}

\section{Result and Discussions}

Descriptive statistics give us a clear and generalized view of the data set. Therefore, we start our discussion with reporting descriptive statistics in Table 3 where the average level of OFDI as a percentage of GDP is 1.45 while the average level of IFDI as a percentage of GDP is 2.50 . This shows that foreign investment in the GCC countries on average is higher than the GCC countries investment abroad. Normally, it is perceived that strong government control means more public and less private investment, but average public investment in the GCC countries as a percent of GDP is almost half 
that of average private investment (Table 3). The GCC countries registered 5.25 percent growth rate on average in the last two and half decades. OFDI, IFDI, IR and other variables report relatively small variation across the panels; however, there is big difference in the trade as share of GDP across the GCC countries.

Table 3. Descriptive statistics.

\begin{tabular}{cccccc}
\hline Variable & Obs & Mean & Std. Dev. & Min & Max \\
\hline DPI & 150 & 24.20 & 11.72 & 8.50 & 69.50 \\
\hline OFDI & 150 & 1.52 & 4.20 & -11.12 & 10.22 \\
\hline GR & 150 & 5.32 & 6.40 & -6.22 & 30.52 \\
\hline IFDI & 150 & 2.50 & 4.65 & -7.34 & 36.72 \\
\hline IR & 150 & 3.75 & 4.50 & 0.10 & 7.25 \\
\hline TO & 150 & 88.28 & 42.55 & 60.72 & 188.90 \\
\hline PUB & 150 & 14.42 & 9.88 & 5.40 & 49.40 \\
\hline
\end{tabular}

The GCC countries are closely linked and their economic interdependence has further increased in the last few decades. The peculiar nature of the GCC countries gives way to suspension that our selected variables may suffer from the problem of cross-sectional dependence. Therefore, we use [56] $\mathrm{CD}$ (cross sectional dependence) test to investigate contemporaneous correlation in our panel series. The null hypothesis in the [56] CD test is cross-sectional independence while the alternative hypothesis suggest presence of cross-sectional dependence in the panel data. CD test values in Tables 4-6 reports highly significant cross-sectional dependence in the data across the board.

Keeping in view the diverse nature and size of the GCC countries, we applied the Breusch-Pagan test of homoscedasticity in order to determine whether our data sets exhibit constant or non-constant variance in cross-sections. The Breusch-Pagan test statistic in Table 4 for the baseline and extended models are highly significant and thus they reject the null hypothesis of homogeneity in data. The data also report a serial correlation problem. This means that the cross-sectional dependence, heteroscedasticity and serial correlation problem in our dataset leave the traditional panel estimation techniques redundant. The only option left are feasibly generalized least square and panel corrected standard errors (PCSE) test. FGLS and PCSE produce efficient and consistent estimators in the case of cross-sectional dependence and group hetero in the data set. Though our main purpose of this study is to explore the impact of OFDI on private investment, but we start our analysis with the impact of OFDI on overall investment in the GCC countries. The main reason of doing this is to better understand the contribution of OFDI to private investment in the GCC countries.

The FGLS and PCSE results in Table 4 suggest that the impact of OFDI, GDP growth and trade openness on overall investment in the GCC countries are insignificant. In Table 4 only incoming FDI assert a positive and significant influence on the overall investment. The insignificant impact of GDP growth rate and trade on overall investment in Table 4 indicates that the GCC countries relied on natural resources in their export to rest of the world while the products required at home were imported from abroad. Therefore, despite many-fold increase in trade and GDP, the domestic investment is still out of touch with the two most important macroeconomic variables. Interest rate (IR) is another important variable which carry a correct sign but assert insignificant influence on domestic investment in the GCC countries. 
Table 4. Impact of OFDI on overall investment.

\begin{tabular}{|c|c|c|c|c|}
\hline \multirow{2}{*}{ Variables } & \multicolumn{2}{|c|}{ Model 1} & \multicolumn{2}{|c|}{ Model 2} \\
\hline & FGLS & PSCE & FGLS & PCSE \\
\hline OFDI & 0.0339 & 0.0544 & 0.0628 & 0.0728 \\
\hline IFDI & $0.0142 * * *$ & $0.0394 * *$ & $0.0062 * *$ & $0.0370 * *$ \\
\hline GDP & 0.4423 & 0.5236 & 0.5421 & 0.6235 \\
\hline IR & -0.0733 & -0.0583 & -0.0417 & -0.5495 \\
\hline $\mathrm{TO}$ & & & 0.0127 & 0.0092 \\
\hline Constant & 21.883 * & 21.827 * & 22.078 * & 22.038 * \\
\hline Wald test $P$ value & 0.6339 & 0.8895 & 0.7778 & 0.9567 \\
\hline \multicolumn{5}{|c|}{ CD and Other Tests } \\
\hline CSD & $8.282 *$ & $8.282 *$ & $9.568 *$ & $9.568 *$ \\
\hline Xttest2 & $96.25 *$ & $96.25 *$ & 85.23 * & 85.23 * \\
\hline Serial & $97.74 *$ & $97.74 *$ & $97.01 *$ & 97.01 * \\
\hline
\end{tabular}

In light of the above findings now we come to our main question. Does OFDI affect private investment in GCC countries? Table 5 report the impact of OFDI, IFDI and other variables (in model 2) on domestic private investment in the GCC countries. The results show that contrary to OFDI impact on the overall investment, the impact of OFDI on private investment in the GCC countries is positive where one percent increases in OFDI increases private capital from 0.23 percent of 0.31 percent. This shows that OFDI complement private investment. This finding, when compared with the impact of OFDI on overall investment, provides a policy direction that OFDI can be instrumental in diversification of the GCC countries.

Table 5. Impact of OFDI on private investment.

\begin{tabular}{|c|c|c|c|c|c|c|}
\hline \multirow{2}{*}{ Variables } & \multicolumn{2}{|c|}{ Model 1} & \multicolumn{2}{|c|}{ Model 2} & \multicolumn{2}{|c|}{ Model 3} \\
\hline & FGLS & PCSE & FGLS & PCSE & FGLS & PCSE \\
\hline OFDI & $0.2316^{* * *}$ & $0.3833 *$ & 0.2229 & 0.3867 * & $0.2736 * *$ & 0.4251 * \\
\hline IFDI & 0.1656 & $0.1199^{* * *}$ & 0.1378 & $0.1221 * *$ & 0.1604 & $0.1102 * *$ \\
\hline GDP & 0.0533 & 0.0211 & 0.0500 & 0.0179 & 0.0348 & 0.0682 \\
\hline IR & $-0.0186^{* *}$ & $-0.0201^{* *}$ & $-0.0221 * *$ & $-0.0199 * *$ & $-0.0254^{* *}$ & -0.0190 * \\
\hline $\mathrm{TO}$ & & & $0.0228^{* * *}$ & 0.0179 & $0.0345^{* *}$ & 0.0273 \\
\hline PUB & & & & & $0.3410 *$ & 0.1991 \\
\hline Constant & $24.815 *$ & $25.53 *$ & $22.199 *$ & $4.00 * *$ & $16.87^{*}$ & $20.16^{*}$ \\
\hline Wald test $p$-values & 0.2672 & 0.1219 & 0.1154 & 0.1962 & 0.0004 & 0.1222 \\
\hline \multicolumn{7}{|c|}{ CD and Other Tests } \\
\hline $\mathrm{CD}$ & $8.011 *$ & $8.011 *$ & $6.341 *$ & $6.341 *$ & $2.742 *$ & $2.742 *$ \\
\hline B-P LM Test & $251.35 *$ & $251.35 *$ & $344.47^{*}$ & $344.47 *$ & $254.71 *$ & $254.71 *$ \\
\hline Serial. & $22.353 *$ & $22.353 *$ & $22.279 *$ & $22.279 *$ & 32.106 * & $32.10 *$ \\
\hline
\end{tabular}


Table 5 also shows that GDP growth did not influence private capital formation and this finding is in line with [15] who shows that one-way causality runs from private investment to GDP while GDP does not cause private investment. Trade impact on private investment is positive and significant, but not very strong. On average, a percent increase in trade enhances private investment by 0.03 percent, which is marginal. This shows that the trade in the GCC countries is not properly connected to global chain of production. Yet, when we look into the big chunk of hydrocarbon in the GCC export and the efforts of the GCC countries to substitute imports with local products, the results seems satisfactory. The impact of IFDI in Table 5 is significant, but only under PSCE models. Simply, Table 5 shows that OFDI can be an effective tool to promote private investment in the GCC countries.

The positive and significant role of public sector in private investment in Table 5 indicates that public sector crowd in private investment in the GCC countries. This finding negates the crowd-out hypothesis of public private investment of neoclassical and supports the crowd-in hypothesis of the Keynesian which shed positive light on the role of government in providing the private investment with the required infrastructure and the necessary support. The presence of public sector also enhances the values of OFDI impact on private investment and it reaches maximum to 0.4 in the presence of public capital (in model 3 of Table 5).

From Table 4 and 5 we can draw a conclusion that OFDI does not affect overall investment in the GCC countries, but OFDI strongly affect private investment in the GCC countries. OFDI impact on private investment in Table 5 is higher than IFDI impact on private investment and therefore, OFDI can be used as a policy instrument to diversify local economies in the GCC countries. Now to take the discussion a bit further, we replace private investment (DPI) by public investment (PUB) in Equation (2). The main purpose of this exercise is to understand whether OFDI and private investment has any impact on public investment. Table 6 reports that in the base line model (under FGLS and PCSE) OFDI does not affect public investment, only IFDI and GDP growth and interest rate significantly affect public investment. However, the impact of the GDP growth and IFDI is quite different. GDP is adversely affecting public investment while IFDI is positively contributing to it. This shows that as GDP of the GCC countries grow, the share of public investment decrease. Table 6 shows that interest rate does not affect public investment in the GCC countries.

Table 6. Impact of OFDI on public investment.

\begin{tabular}{|c|c|c|c|c|c|c|}
\hline \multirow[t]{2}{*}{ Variables } & \multicolumn{2}{|c|}{ Model 1} & \multicolumn{2}{|c|}{ Model 2} & \multicolumn{2}{|c|}{ Model3 } \\
\hline & Gls & Pcse & Gls & Pcse & Gls & Pcse \\
\hline OFDI & -0.0287 & -0.0165 & -0.0120 & -0.0108 & -0.0458 & -0.0159 \\
\hline FDI & $0.0654^{* *}$ & $0.0584 * *$ & $0.0500 * *$ & 0.0593 * & $0.0477 *$ & -0.0413 * \\
\hline GDP & $-0.077^{* *}$ & $-0.1581 *$ & $-0.092 * *$ & -0.1031 * & $-0.0811^{*}$ & -0.1272 * \\
\hline IR & 0.0433 & 0.0361 & 0.0275 & 0.0549 & 0.0832 & 0.0474 \\
\hline $\mathrm{TO}$ & & & -0.0183 & -0.0281 & -0.0277 & -0.0174 \\
\hline DPI & & & & & $0.1201 *$ & 0.0123 \\
\hline Constant & $13.45^{*}$ & $15.90 *$ & $14.01^{* *}$ & 16.51 * & $10.80 *$ & $16.15^{*}$ \\
\hline Wald Test $p$-values & 0.1262 & 0.0321 & 0.1807 & 0.0573 & 0.0171 & 0.1363 \\
\hline \multicolumn{7}{|c|}{ CD and Other Tests } \\
\hline CSD & $8.491 *$ & 8.491 * & $6.569 *$ & $6.569 *$ & $3.917 *$ & $3.917 *$ \\
\hline B-P LM Test & $551.3^{*}$ & $551.39 *$ & $639.02 *$ & $639.02 *$ & $298.76^{*}$ & $298.76^{*}$ \\
\hline Serial & $9.794 *$ & $9.794 *$ & $10.813^{*}$ & $10.813 *$ & $11.375 *$ & 11.375 * \\
\hline
\end{tabular}


In the extended models, only private investment under FGLS model significantly and positively affects public investment which again shows that public and private investment are mutually crowding in each other in the GCC countries. The mutual positive impact of the public and private investment on each other not only confirms the crowding-in Keynesian hypothesis, but it is also a good reflection of the reality in the GCC countries where public sector investment in infrastructure asserted a positive spill over impact on the private economy [1]. Public sector investment in the GCC countries increases the confidence of private investors, reduce their cost of doing business and it provides them assurance that the government support is behind them.

\section{Conclusions}

This study investigates the impact of outbound foreign direct investment on the domestic private investment in the GCC countries keeping in view the cross-sectional dependence in the GCC countries. Relying on FGLS and PCSE approaches, the findings of the study suggest that OFDI significantly boost private investment in the GCC countries. This shows that OFDI complement private investment and economic activities in the private sector in the GCC countries. The strong complementary impact of OFDI on private investment with significantly high coefficient makes it an exception tool by which the GCC countries can diversify their economies and can encourage local investors. OFDI can be a good policy tool in the GCC countries to encourage private investment and diversify economic activities away from hydrocarbon. This study also found that OFDI do not assert significant influence on aggregate domestic investment. However, such finding cannot be generalized for sectoral level analysis. OFDI exhibit different pattern when we divide domestic capital formation into private and public capital formation. OFDI significantly increase private capital formation in the GCC countries while the role of OFDI in promoting public capital formation is insignificant. This shows that OFDI is not only effective in economic diversification, but it is also a good tool to reduce the disparity between public and private investment in the GCC countries. Keeping in view the cross sectional dependence in the data we used FGLS and PCSE and found that OFDI does not affect overall investment in the GCC countries, but it strongly affects private investment. Thus, OFDI can be used as policy instrument to diversify the hydro carbon dependent GCC economies.

Author Contributions: Conceptualization, Formal analysis, Writing-original draft (S.H.S.).; Conceptualization, Methodology, Formal analysis (W.A.).; Conceptualization, Literature Review, Conclusion and Supervision (S.D.).; All authors have read and agreed to the published version of the manuscript.

Funding: This research was funded by the International Innovation Team Project of China, grant number 2019GJTD03.

Acknowledgments: Authors are thankful to the five anonymous reviewers for their insightful and constructive comments to improve this article.

Conflicts of Interest: The authors declare no conflict of interest to disclose.

Note: All the data used in this study is available on demand.

\section{Appendix A}

Fixed and random effect results in Table A1 shows that except OFDI all the other variables insignificantly affect private investment as a whole. The diagnostic test reported in Table A1 indicate serious problem in running the FE/RE models (based on Equations 1 and 2 in the main text) and therefore we rely on FGLS and PCSE results in the main text. 
Table A1. DPI as dependent variables.

\begin{tabular}{ccccc}
\hline \multirow{2}{*}{ Variables } & \multicolumn{2}{c}{ Model 1 } & \multicolumn{2}{c}{ Model 2 } \\
\cline { 2 - 5 } & F.E & R.E & F.E & R.E \\
\hline OFDI & $0.250^{* *}(2.04)$ & $0.217^{*}(1.75)$ & $0.265^{* *}(2.14)$ & $0.241^{* *}(1.95)$ \\
\hline IFDI & $-0.083(0.455)$ & $-0.039(-0.35)$ & $-0.056(-0.49)$ & $-0.028(-0.25)$ \\
\hline GDP & $-0.042^{(-0.59)}$ & $-0.049(-0.69)$ & $-0.038(-0.53)$ & $-0.043(-0.61)$ \\
\hline TO & & & $-0.012(-1.16)$ & $-0.011(-1.06)$ \\
\hline IR & & & $0.155(1.32)$ & $0.401(1.16)$ \\
\hline PUB & & & $0.885^{* * *}(9.32)$ & $0.408^{* * *}(4.16)$ \\
\hline Constant & $21.262^{* * *}(36.13)$ & $21.248^{* * *}(21.52)$ & $22.331^{* *}(20.35)$ & $21.216^{* * *}(14.86)$ \\
\hline Wald $P$ value & 0.6339 & 0.8895 & 0.7778 & 0.9567 \\
\hline Hausman Test & & 0.0038 & & 0.0315 \\
\hline CSD & $8.282^{* * *}$ & $8.282^{* * *}$ & $9.568^{* * *}$ & $9.568^{* * *}$ \\
\hline Xttest2 & $96.25^{* * *}$ & $96.25^{* * *}$ & $85.23^{* * *}$ & $85.23^{* * *}$ \\
\hline Serial & $97.74^{* * *}$ & $97.74^{* * *}$ & $97.01^{* * *}$ & $97.01^{* * *}$ \\
\hline
\end{tabular}

Note: “*”, " "*** and ${ }^{\text { } * * * * \prime}$ represent significance at $1 \%, 5 \%$ and $10 \%$, respectively. $Z(t$-bar) values are reported in the brackets().

\section{References}

1. IMF. Trade and Foreign Investment_-Keys to Diversification and Growth in the GCC; IMF Policy Paper; International Monetary Fund: Washington, DC, USA, 2018.

2. Frankel, J.A. The Natural Resource Curse: A Survey; No. w15836; National Bureau of Economic Research: Cambridge, MA, USA, 2010.

3. De Mello, L.R. Foreign direct investment in developing countries and growth: A selective survey. J. Dev. Stud. 1997, 34, 1-34. [CrossRef]

4. Braunstein, E.; Epstein, G. Bargaining Power and Foreign Direct Investment in China: Can 1.3 Billion Consumers Tame the Multinationals? CEPA Working Paper 2002/13; Centre for Economic Policy Analysis: New York, NY, USA, 2002.

5. Kumar, N.; Pradhan, J.P. FDI, Externalities, and Economic Growth in Developing Countries: Some Empirical Explorations and Implications for WTO Negotiations on Investment; RIS Discussion Paper No. 27/2002; Research and Information System for Developing Countries: New Delhi, India, 2002.

6. Khalifah, A. Macroeconomic Competitiveness of the GCC Economies. In The GCC Economies; Ramady, M.A., Ed.; Springer: New York, NY, USA, 2012; pp. 1-324.

7. Al-Sadig, A.J. Outward Foreign Direct Investment and Domestic Investment: The Case of Developing Countries; Working Paper no. 13/52/2013; Int. Monetary Fund: Washington, DC, USA, 2013; pp. 1-27.

8. Desai, M.A.; Foley, C.F.; Hines, J. Foreign Direct Investment and the Domestic Capital Stock. Am. Econ. Rev. 2005, 95, 33-38. [CrossRef]

9. Mazumdar, S. BRICS: From FDI Destination to Departure Point. The Economic Times, 10 February 2014.

10. Stevens, G.V.G.; Lipsey, R. Interactions between Domestic and Foreign Investment. J. Int. Money Financ. 1992, 11, 40-62. [CrossRef]

11. Arndt, C.; Buch, C.; Schnitzler, M. FDI and Domestic Investment: An Industry-Level View; CEPR Discussion Papers; Deutsche Bundesbank: Frankfurt, Germany, 2007; p. 6464.

12. Hejazi, W.; Pauly, P.H. Motivations for FDI and Domestic Capital Formation. J. Int. Bus. Stud. 2005, 34, 282-289. [CrossRef]

13. Igor, G.; Mario, H.; Gilmar, M. Effects of Outward Foreign Direct Investment on Domestic Investment: The Cases of Brazil and China. J. Int. Dev. 2018, 30, 1439-1454.

14. Ameer, W.; Xu, H.; Alotaish, M.S.M. Outward Foreign Direct Investment and Domestic Investment: Evidence from China. Econ. Res.-Ekon. Istraživanja 2017, 30, 777-788. [CrossRef] 
15. Khan, M.S.; Reinhart, C. Private Investment and Economic Growth in Developing Countries; World Bank: Washington, DC, USA, 1990; pp. 19-27.

16. Callen, M.T.; Hasanov, C.F.; Hegazy, M.A.; Khandelwal, P. Economic Diversification in the GCC: Past, Present, and Future; Int. Monetary Fund: Washington, DC, USA, 2014.

17. Ganguli, S. An economic analysis of the sustainability of a potential GCC economic and monetary union during 2005-2014. World J. Entrep. Manag. Sustain. Dev. 2016, 12, 194-206. [CrossRef]

18. Beblawi, H.E.L. Gulf industrialization in perspective. In Industrialization in the Gulf: A Socioeconomic Revolution; Seznec, J.-F., Kirk, M., Eds.; Center for Contemporary Arab Studies, Georgetown University/Routledge: London, UK, 2011; pp. 185-197.

19. Al-Iriani, M. Foreign Direct Investment and Economic Growth in the GCC Countries: A Causality Investigation Using Heterogeneous Panel Analysis. Top. Middle East. N. Afr. Econ. 2007, 9, 1-31.

20. Ghassan, H.B.; Alhajhoj, H.R. Long Run Relationship between IFDI and Domestic Investment in GCC Countries. J. Econ. Econom. 2016, 59, 16-43.

21. Hansen, H.; Rand, J. On the Causal Links Between FDI and Growth in Developing Countries. World Econ. 2006, 29, 21-41. [CrossRef]

22. Feldstein, M. The Effects of Outbound Foreign Direct Investment on the Domestic Capital Stock; Working Paper no. 4668; National Bureau of Economic Research: Cambridge, MA, USA, 1994; pp. 1-34.

23. Feldstein, M. The Effects of Outbound Foreign Direct Investment on the Domestic Capital Stock. In The Effects of Taxation on Multinational Corporations; Robert, E.L., Ed.; University of Chicago Press: Chicago, IL, USA, 1995; pp. 43-66.

24. Braunerhjelm, P.; Oxelheim, L.; Thulin, P. The relationship between domestic and outward foreign direct investment: The role of industry-specific effects. Int. Bus. Rev. 2006, 14, 677-694. [CrossRef]

25. Shah, H.S.; Hafsa, H.; Junjiang, L. Does Chinese Investment Contribute to The US Economy? An Analysis of Selected US States' Growth, Employment and Exports. Braz. J. Bus. Econ. 2014, 14, 7-20.

26. Kim, D.K.D.; Seo, J.-S. Does FDI inflow crowd out domestic investment in Korea? J. Econ. Stud. 2003, 30, 605-622. [CrossRef]

27. Faeth, I. Consequences of FDI in Australia-Causal Links between FDI, Domestic Investment, Economic Growth and Trade; Paper No. 977; Department of Economics Research: Melbourne, Australia, 2006.

28. Jefferson, A.C.; Tiago, R.L.; Joaa, C. Does Foreign Porfolio Capital Flows Affect Domestic Investment? Evidence from Brazil. Int. J. Financ. Econ. 2018, 24, 855-883.

29. Herzer, D.; Schrooten, M. Outward FDI and Domestic Investment; DIW Discussion Papers No. 679; Deutsches Institut für Wirtschaftsforschung : Berlin, Germany, 2007.

30. Dunning, J.H. Multinational Enterprises and the Global Economy; Addison-Wesley: Wokinghan, UK, 1993.

31. You, K.; Solomon, O.H. China's Outward Foreign Direct Investment and Domestic Investment: An Industrial Level Analysis. China Econ. Rev. 2015, 34, 1-39. [CrossRef]

32. Shah, H.S.; Ahmad, M.H.; Ahmad, Q.M. The Nexus between Sectoral FDI and Institutional Quality: Empirical Evidence from Pakistan. Appl. Econ. 2016, 48, 1591-1601. [CrossRef]

33. Kamal, M.A.; Shah, S.H.; Jing, W.; Hafsa, H. Does the Quality of Institutions in Host Countries Affect the Location Choice of Chinese OFDI: Evidence from Asia and Africa. Emerg. Mark. Financ. Trade 2019. [CrossRef]

34. Zhang, K.H. Does foreign direct investment promote economic growth? Evidence from East Asia and Latin America. Contemp. Econ. Policy 2001, 19, 175-185. [CrossRef]

35. Andersen, P.; Hainaut, P. Foreign Direct Investment and Employment in the Industrial Countries; BIS Working Papers; Bank for International Settlements: Basel, Switzerland, 1998; Volume 61, pp. 1-49.

36. Narayan, P.K. Do public investments crowd out private investments? Fresh evidence from Fiji. J. Policy Model. 2004, 26, 747-753. [CrossRef]

37. Shah, H.S.; Hafsa, H.; Simon, C.; Mohsin, H.A. Sectroal FDI Inflows and Domestic Investment in Pakistan. J. Policy Model. 2019. [CrossRef]

38. Mark, N.C.; Sul, D. Cointegration vector estimation by panel DOLS and long-run money demand. Oxf. Bull. Econ. Stat. 2003, 65, 655-680. [CrossRef]

39. Pedroni, P. Purchasing Power Parity Tests in Cointegrated Panels. Rev. Econ. Stat. 2001, 83, 727-731. [CrossRef] 
40. Pesaran, M.H.; Shin, Y.; Smith, R. Pooled Mean Group Estimation of Dynamic Heterogeneous Panels. J. Am. Stat. Assoc. 1999, 94, 621-634. [CrossRef]

41. Kmenta, J. Elements of Econometrics; Macmillan: New York, NY, USA, 1986.

42. Hicks, A. Introduction to Pooling. In The Comparative Political Economy of the Welfare State; Janoski, T., Hicks, A., Eds.; Cambridge University Press: Cambridge, UK, 1994; pp. 169-188.

43. Arellano, M.; Bond, S. Some tests of specification for panel data: Monte Carlo evidence and an application to employment equations. Rev. Econ. Stud. 1991, 58, 277-297. [CrossRef]

44. Parks, R.W. Efficient estimation of a system of regression equations when disturbances are both serially and contemporaneously correlated. J. Am. Stat. Assoc. 1967, 62, 500-509. [CrossRef]

45. Beck, N.; Katz, J.N. What to do (and not to do) with time-series cross-section data. Am. Political Sci. Rev. 1995, 89, 634-647. [CrossRef]

46. Al Mamun, M.; Sohag, K.; Uddin, G.S.; Shahbaz, M. Remittance and domestic labor productivity: Evidence from remittance recipient countries. Econ. Model. 2015, 47, 207-218. [CrossRef]

47. Plümper, T.; Troeger, V.E.; Manow, P. Panel data analysis in comparative politics: Linking method to theory. Eur. J. Political Res. 2005, 44, 327-354. [CrossRef]

48. Chudik, A.; Pesaran, M.H.; Tosetti, E. Weak and strong cross-section dependence and estimation of large panels. Econom. J. 2011, 14, C45-C90. [CrossRef]

49. Chudik, A.; Pesaran, M.H. Long-Run Effects in Large Heterogenous Panel Data Models with Cross-Sectionally Correlated Errors. J. Econom. 2015, 188, 393-420. [CrossRef]

50. Reed, W.R.; Ye, H. Which panel data estimator should I use? Appl. Econ. 2011, 43, 985-1000. [CrossRef]

51. Blundell, R.; Bond, S. Initial conditions and moment restrictions in dynamic panel data models. J. Econom. 1998, 87, 115-143. [CrossRef]

52. UNCTAD. World Investment Report; United Nations Conference on Trade and Development: New York, NY, USA; Geneva, Switzerland, 2004.

53. McKinnon, R.I. Money and Capital in Economic Development; The Brookings Institution: Washington, DC, USA, 1973.

54. Erenburg, S.J.; Wohar, M.E. Public and Private Investment: Are there Causal Linkages. J. Macroecon. 1995, 17, 1-30. [CrossRef]

55. Dollar, D.; Kraay, A. Growth is Good for the Poor; Working Paper No. 2587; World Bank Policy Research Department: Washington, DC, USA, 2001.

56. Pesaran, M.H. General Diagnostic Tests for Cross Section Dependence in Panels; CESifo Working Paper Series No. 1229; Cambridge Working Papers in Economics, No. 435; University of Cambridge: Cambridge, UK, 2004.

(C) 2020 by the authors. Licensee MDPI, Basel, Switzerland. This article is an open access article distributed under the terms and conditions of the Creative Commons Attribution (CC BY) license (http://creativecommons.org/licenses/by/4.0/). 